\title{
Globalization and American Power: (Dis)order Through the Politics of Cultural Imperialism
}

\author{
Hana Riani \\ Faculty of Arts and Human Sciences. Sousse. Tunisia
}

\begin{abstract}
As a powerful ideological force, American globalization has played a predominant role in creating a new world (Dis) order based on the premise of hegemonic imperialism. It has shifted the dynamics of US power to a one governed by the politics of global businesses and corporations such as McDonald, Coca Cola, Mickey Mouse, Sony, TV programs, Music and other cultural artifacts. Within this vein, the globalization of American culture strengthens the iconography and influence of the US while eradicating cultural diversity and dehistoricizing "otherized" cultures. The rampant popularity of US cultural commodities across the globe recycles the long-held myths about the power of an exploitative metropolitan global culture dependent on the production, circulation and consumption of American way of life and values. Thus, this article aspires to critically examine the tight correlation between globalization and cultural imperialism where the distant consumer is trapped within the maze of a consuming world driven by capitalist goals. The light is spotted on how Muslims who enjoy what the US has brought to them through high-tech and global industries seem prone to acquiesce to the dictates of the American culture which has in turn exacerbated their state of disorder and wiped their national distinctiveness. The diversification of Islamic movements as a response to Americanized globalization engenders two different waves. While the radical exclusionary Islamic movements portray the relation as a tension between Jihad and Mcworld, the liberal-moderate Islamic movements tend to forge this relation as complementary and communitarian.
\end{abstract}

Key Concepts: Globalization, (Dis)order, Cultural Imperialism, homogenization, Islamic cultural identity

I. INTRODUCTION: "CULTURAL RACISM"

Globalization as a dynamic process impacting heavily on other cultures has created a new world disorder animated by the philosophy of hegemony and domination. Thanks to the sophisticated channels of transmission and global cultural artifacts, it permeates distant boundaries promoting and exporting the imperialistic interests of the western society while wiping and dissolving cultural and national distinctiveness. Thus, this massive wave of homogenization is one of the driving forces behind the westernization of degenerated local cultures acting as a complex mechanism of integration and exclusion, order and disorder, subjugation and preservation. Within this context, global culture and American culture as inextricably linked are widely believed to be a pronounced pronoun of an invisible violence articulated by and through US popular culture. The revitalization of soft dynamics to boost contemporary American power in an age when brutal force is left with no room to thrive, has reinvigorated and legitimized American hegemony to infiltrate and to "oppress" other cultures by eradicating cultural diversity and identities. In fact, in the dark shadow of globalization, the tight correlation between globalization as an economic, political and cultural process strengthening the metaphor of the global village and US culture as the ambassador of a hidden propaganda and imperialism widens the gap that distinguishes the winner from the looser. Within this vein, the realization of a global utopia forged with American traits stresses the iconography of US culture while diluting and dehistoricizing local cultures. This pervasive impact has brought detrimental and traumatic consequences to countries worldwide and to the Muslim culture in particular which has been challenged and tempted by the voracious politics of American globalization. Such intrusion has prompted many to accuse the US with new implications of colonialism which has far-reaching ideological and political implications. By extolling the cultural ideals of freedom, democracy and the American dream, the US has been longing to revive its hegemonic desire of the missionary zeal to propagate its culture and ideology and thus to re-colonize the Muslim world by imposing codes of a new cultural policy carefully oriented to manipulate tastes and to enchant hearts and minds. Therefore, this paper is aspired to examine globalization as a purely American product aimed at boosting consumerism and endorsing capitalism and to assess the extent to which American globalization is a blatant violation of the holy and cultural habits of Muslims. Hence, it intends to portray globalization as a 
colonization in disguise leading and paving the way to a chaotic world order where the emergence of many cultural preservation movements have joined in denunciating the atrocities of cultural "racism" and in shielding the purity of Islamic culture and identity from such incarnations.

\section{GLOBALIZATION THROUGH AMERICAN LENSES: THE EMPIRE'S CULTURAL-IDEOLOGICAL ARSENAL}

With the end of the cold war era and the crumbling of communism, US liberal democracy and capitalism emerge triumphant out of the ashes of the war's ideologies. Since the beginning of 1990's, this new world order based on the premise of American ideals has fueled the exchange of ethos and values and encouraged the integration of societies. While some historians such as Daniel Bell implies that the end of hard power and its culmination in the discourses of war is "the end of Manifest Destiny or the marking of the limits of US Empire" ${ }^{1}$, American cultural imperialism rejuvenates these concerns and revive the idea that the US and its culture, politics and ideals are divinely ordained to save the world and to lead it to betterment. As it is expressed in the words of Stephen Ambrose, "Americans who wanted to bring the blessings of democracy, capitalism, and stability to everyone meant just what they said - the whole world, in their view, should be a reflection of the United States. ${ }^{2}$ This trend resonates with what David Scott coins as "the colonial governmentality" of the new modern logics of colonialism and the modern neoliberal state. ${ }^{3}$ His theorization opens up critical horizons to reflect on the metamorphosing relation of power between colonizers and colonized and engenders a new reading of rewriting colonial history where colonial power is adopting different strategies and working through multiple targets. As such, globalization has become the ambitious project of the US to shift its policies from geo-politics to geo-economics and to construct an imperial enterprise that would serve its hegemonic agenda. The Hollywood movies, television programmes, fast food (e.g. Pizza Hut, McDonalds, and Kentucky Fried Chicken), soft drinks (e.g. Coca-Cola and Pepsi) and Media corporations are seen to disseminate cultural products which marginalize local values. In particular, Americanization has become a symbol of Western dominance to engulf distant cultures and to devour habits and traditions. In fact, the flourishing of discos and malls in the Gulf region, the rampant popularity of Hip Hop and Rap music in Pakistan, the dissolution of the nomadic lifestyle of many Bedouin tribes in Saudi Arabia shed light on an Americanized village where the indigenous culture is subordinated and demeaned. As such, "McDonaldization" and "Coca-Colonization" are deemed as the hegemonic global economy which has accentuated the hypothesis of homogenization to repackage cultural goods as a reference of a universalized culture. Hence, the architecture of this new global village with American ethics is meant to activate and to put into value the politics of cultural imperialism which are aimed at transforming the entire world into a replica of the US consuming the same mass culture and products. Thus, Globalization turned to be the new dress of American cultural imperialism and a new vector of US hegemony in forging ideologies, values and ways of life. From American lenses, globalization is the radical departure from the rhetoric of war to the implementation of soft ways to ensure and engrave America's power worldwide. Therefore, it is reminiscent of Francis Fukuyama's idea that many countries would be inspired to embrace the American model through culture and consumerism: the American way of life would become the world's way of life and thus the very image of a homogenized global village falling prey to the new power and dynamics of US global authority. He argues that "What we may be witnessing is not just the end of the Cold War or the passing of a particular period of post-war history; that is the end point of mankind's ideological evolution and the universalization of Western liberal democracy as the final form of human government". ${ }^{4}$ This link between culture and imperialism and the argument that American culture is eating away local and national eccentricities come from people across the political spectrum. The idea is further developed by Edward Said who points that culture is the appropriate vehicle for imperialist venture. Turning to imperialism, Said notes that instead of being economic, imperialism is intrinsically cultural and argues that "the future would hold not liberation but an extension of imperialism". ${ }^{5}$ An even adherent of globalization like Thomas Friedman, the famous columnist of The New York Times, emphasizes that:

Globalization has a distinctly American face: It wears Mickey Mouse ears, it eats Big Macs, it drinks Coke or Pepsi and it does its computing on an IBM or Apple laptop, using Windows

\footnotetext{
${ }^{1}$ Daniel Bell, The Winding Passage: Essays and Sociological Journeys, 1960-1980, (Cambridge, MA: Abt, Books, 1980).

${ }^{2}$ Stephen E. Ambrose, Rise to Globalism: American Foreign Policy since 1938, 3rd ed (Pelican, 1983), p. 19.

${ }^{3}$ David Scott, “Colonial Governmentality”, Social Text, 43, (Autumn 1995):197:8.

${ }^{4}$ Francis Fukuyama, The End of History and The Last Man, (N.Y: New York Press, 1992), p. 3.

${ }^{5}$ Edward Said, Culture and Imperialism, New York: Knopf: 1993), p. 167.
} 
98[...]. In most societies, people cannot distinguish any more between American power, American exports, American cultural assaults, American cultural exports and plain vanilla globalization. They are now all wrapped into one. Many societies around the world can't get enough of it, but others see it as a fundamental threat. ${ }^{6}$

Since culture becomes an umbrella term for a complex alterations, US domination of the cultural sphere points to the sharp contrast of the new world order and the embedded contradictions of globalization as a benign evil and as "the prevalent divide between a cohesive, prosperous and peaceful bloc of liberal states and the instability and chaos of the rest of the world". ${ }^{7}$ A close examination of the process of American cultural diffusion spots light on how cultural and technological "manifest destiny" 8 espouses the long-held myth and the desire of the US to inject its ideology worldwide. Indeed, the roots for American imperialism stem from the mentality that "a more perfect civilization will arise to bless the earth". ${ }^{9}$ The motivations fuelling cultural imperialism parallel the justifications for US colonial past when old settlers masscrated and assimilated the "savage" Indian tribes. Throughout history, the idea of the US as an extraordinary and exceptional nation has made the Para-ideological umbrella beneath which extend related concepts such as "American Exceptionalism", "A City upon a Hill", and "Social Darwinism" to represent the basis of American prodigiosity. It is this arrogant belief in the superiority of American culture which foregrounds the fundamental assumption that cultural globalization is the catalyst for the prevailing process of subjugation through distraction, consumerism and leisure. So, as the bastion of civilization and the unrivalled superpower, the consolidation of the contemporary American empire no longer depends on its military and diplomatic cloud but leans heavily on the dissemination of its cultural artifacts and icons to lead and reign globally. The revival of the same old imperialism yet equipped with soft tools and motivations characterize the new face of American globalization as a newly orchestrated imperial enterprise that favors US values. Paul Gilroy maintains that "the accumulation of capital is no longer fed by mere exploitation of the labour force. It depends increasingly on the manipulation of complex organizational and informational systems". ${ }^{10}$ Thus, American globalization is another form of the invisible coercive subjugation of non-western societies which fall trapped within the maze of an illusionary consumerist world driven by selfish capitalist interests. From music to movies, literature to language, food to clothes, the American model is flinging into every corner of the globe. Li Delun, the director of the musical central philharmonic Orchestra of China confirms that "the floodgates have been opened and we have an unprecedented inundation. Since world war, mass culture from the US- from jazz to disco- has conquered the world". ${ }^{11}$

Based on the culture of consumerism and that happiness comes from commodities, American cultural imperialism increases the dependency between the US as the nation of dreams, prosperity and modernity and the third world as an impoverished and exploited nation surrendering to the imperial impulses of the colonizing culture. This periphery-core relation has exacerbated and contributed to cultural erosion and the endangering of the "other" cultural identity and traditions. Backed by clever advertising machines and sophisticated technology, images of American life-style and values are circulated with great ease yet loaded with hegemonic goals to create a massive wave of synchronization. In fact, what is sold is not only products or artificial needs but the image of America as ideal and alluring. This indissoluble connection drives consumers to clamor for American goods and thus become unable to reconcile their traditional values with the dominating culture. The assumption that the twentieth century is the "culture of narcissism" and the "one dimensional society" ${ }^{12}$ where the increasing centrality of US culture grows stronger implies that common to all these accounts is the idea that America holds and enjoys an iconic position standing as a beacon in an interconnected world. Such cultural shift justifies the conviction that the proliferation of US cultural products and commodities highlights the transition from a

\footnotetext{
${ }^{6}$ Thomas Friedman, "Commentary: Why Those Angry Men Want to Kill America", The New York Times, Aug. 25, 1998 , p. 7.

${ }^{7}$ Andrew Hurrel and Ngaire Woods, "Globalization and Inequality", in Millennium. Journal of International Relations 24.3 (1995):447:470.

${ }^{8}$ Renehan, Edward, The Monroe Doctrine: The Cornerstone of American Foreign Policy, (New York: Info Base Publishing, 2007).

9 Jerel A Rosati, The Politics of United States Foreign Policy, (Orlando: Harcourt Brace College Publishers, 1999), p. 26.

${ }^{10}$ Paul Gilroy, There Ain't No Black in The Union Jack: The Cultural Politics of Race and Nation, (University of Chicago Press: Chicago, 1995), p. 225.

${ }^{11}$ Cited in Orville Shell, "Discos and Democracy", Mother Jones Magazine, June 1988, p. 9.

${ }^{12}$ Herbert Marcuse, One Dimensional Man: Studies in The Ideology of Advanced Industrial Society, (Boston: Beacon, 1964), p. 9.
} 
"situated" to a "globalized" culture. ${ }^{13}$ In its drive for hegemony, the US has confirmed the claim that every power organizes "hegemonic space in terms of its own interests and purpose"14 ${ }^{14}$ where the very structure of the world is defined by American assumptions and aspirations. As a melting pot and an amalgam of different cultures, the US has sought to repackage cultural products in a way to appeal to different tastes. In recent years, American corporations have developed a reconciliating-global strategy to pitch diversity by masking the imperial orientations of the homogenization process. Instead of promoting American conformity to indoctrinate consumers by drawing on ideal stereotypical Americans who are entitled to circulate and secure dominant ideological representations, the US resorts to hybridize its campaigns. McDonald alters its menus to conform to local tastes and with its international campaign "I'm loving it" burnishes the image of the US as a powerful hybrid and an embodiment of integrated histories, cultures and ethnicities. An instance of early marketing tactics was reflected in 1971's Coca Cola commercial which portrayed children from diverse countries singing peacefully "I'd like to teach the world to sing in perfect harmony. I'd like to buy the world a Coke to keep it company." This strategy mirrors America as a world culture capable of transcending cultural barriers, ethnic, political and religious differences where world peace could be achieved through the politics of consumerism. One of the ways to adopt this strategy is fulfilled by MTV which blends different tastes while involving and keeping viewers within the realm of a hyperreal Americanized world. According to New World Teen Study in forty-five countries, $85 \%$ watch MTV every day. Through the power of visual images, the twenty-four parade of celebrity music shows a utopic view of US culture. Proliferated by MTV, countless of music icons such as Britney Spears, Madonna, Beyonce and Puff Daddy are promoted as a highly cultural symbol dragging teens to absorb what is displayed as a mixture of cultural influences. Perpetuated and created by and through the media, celebrity becomes understood and evaluated as a media-constructed phenomenon, the very societal pinnacle that has and continues to be an ubiquitous component of American culture and "in many respects, America's dominant ethos... new common denominator". ${ }^{15}$ Also, the insertions of indigenous celebrities assimilate many local cultures to the subtle but effective power of imperialism. The association between modernity and Americanism has been extended to far-flung countries such as India. Bollywoood stars such as Hrithik Roshan and Sharukh Khan are promoting the soft drinks of Pepsi and Coca Cola.

This cultural imperialism articulated by the US is boosted by giant media corporations and popular culture industries which play an important role to ensure that the ideology at play remains encompassing, "amerocentric" and pluralistic to reach worldwide audiences. With the dawn of the new millennium, the media become more technologically dazzling with tempting spectacles to fascinate consumers and to involve them in the semiotics of a new world order orchestrated on the consumption of images and staged events. If before the 1990 's, media systems in most countries were national in scope, international flow of information assisted by the development of American global capitalism, deregulation policies and increasing commercialization of TV to permit the proliferation of satellite channels, ensure the evolution of the US from modernization and internationalism to cultural imperialism and domination. Television genre formats such as talk show, sitcoms, reality show, comedy as well as infotainment accentuate the values of capitalist consumerism and individualism hence establishing a relationship of subordination in regard to the rest of the world and mainly the Third World which has lost its cultural autonomy in this long journey of virtual and cultural "war". To compound the influence of commercial images, the media perpetuate explicit and implicit messages about the military and economic hegemony of the US and thus play an undeniable role in the propagation of US agenda. CNN and Fox News present foreign countries with unabashed accounts of the ascendency of the US in an attempt to heighten the equation of inequality. Thus, postcolonial encounters between imperial America and conquered cultures are pervasive in an informational age where Time Warner, Disney, Viacom, News Corporation, Sony and Phillips are the new ties for cultural domination. As such, the "soft power" 16 of this new world order fosters a false propaganda of the US as "inveterate liberals and anti-imperialists". ${ }^{17}$ The driving reason for such delusion, as Said puts it is that "the rhetoric of power all too easily produces an illusion of benevolence when deployed in imperial settings". ${ }^{18}$ In fact, one of the most far-reaching impacts of American globalization is the Americanization of the Third World and mainly the Islamic world which is bombarded with impulsive flimsy

\footnotetext{
${ }^{13}$ Neal Gabler, Life The Movie: How Entertainment Conquered Reality, (Toronto: Random House of Canada, 1998), p. 167.

${ }^{14}$ Robert Gilpin, “The Politics of Transnational Economic Relations”, in Keohane, R.O. and Nye, J. Power and Independence: Politics In Transitions, (Boston: Addison Wesley, 1971), p. 153.

${ }^{15}$ Neal Gabler, Walter Winchell: Gossip, Power and The Culture of Celebrity, (London: Picador, 1995), p. 12.

${ }^{16}$ Soft power is a term coined by Joseph Nye in the late 1980's to refer to the ability of a country to persuade through attraction rather than coercion.

${ }^{17}$ Susan Strange, "Towards a Theory of Transnational Empire", in Czempiel and Rosenau (Ed) Global Changes and Theoretical Challenges, (Lexington: Lexington Books, 1989), p. 177.

${ }^{18}$ Said, Culture and Imperialism, p. 19. 
values. Deeply rooted in Muslim countries, US ideals are imposed on the economic, cultural and social aspects of the people of the East, specifically Muslims. In the light of the ferocious onslaught of the waves of imperialism which have touched their shores and tainted their very identity and culture, it becomes obvious that the latter are the target of a new "cultural-civilizing mission" animated by the ideologies and the vibrations of American Manifest Destiny and exceptionalism.

\section{MONOCULTURE AND “TEMPTED” ISLAMIC IDENTITY: CULTURAL NEO- ORIENTALISM}

In the age of global geopolitics and neo-liberal globalization, space and time have been minimized where the" rest" are seen either on the inescapable path to embrace models of modernity and liberalism or are labeled as places of clashes, antagonism, or even as rough states. ${ }^{19}$ The successive decline of Islamic empires starting with Baghdad and the Ottoman Empire with its marked civilization and intellectualism left Muslims in a pathetic situation which aggravated the wounds of their world in regaining a prestigious position and in being able to face the new imposed challenges. Many shifts and alterations in Islamic history weakened Muslims and made them non immune to exterior powers and agendas. The monstrous growth of US culture thanks to the machinations of globalization stimulates American hegemony through economic domination and cultural mimesis and forges a cultural hybridization in a vulnerable Islamic world. Recently, the manifestation of neoimperialism is a real challenge to the integrity, purity and regeneration of local cultures where "the cultural pressures of globalization are keenly felt in the Muslim world". ${ }^{20}$ In this regard, Islamic culture has come into conflict with a subverting alien culture globalized by media and popular artifacts. The inclination of non-Islamic cultural substances is reflected in many Muslim societies as the multi-dimensional power of globalization ramifies into all areas of life. Indeed, the secular American culture has find way to fill the vacuum left by a faraway golden age of Muslim's accomplishments. The real dilemma is the vivid contrast between "hybridity" and "authenticity" as Islamic cultural identity thrives to shield its integrity and homogeneity as grounded on both rational and religious principles from the temptations of American values which are driven by rationality and secularism. In fact, in modern times the brunt of American subjugation as a western tradition is obviously seen in how Muslim countries develop an extreme dependence on the west to survive the new challenges in the areas of technology, culture and education. To make them fall under the thrall of a seducing narcisstic culture is the revisited version of US neo-colonialism to propel the new policies of expansionism in a global age. As such, the American culture is there to assist the Muslim world with progress, development, leisure, satisfaction and facilities and to protect it from degradation and backwardness. This new process of bringing civilization in the guise of consumerism enables the US to safeguard its interests and to restore its colonial parameters while targeting Muslims' culture and intimidating its power.

This discontent in the aura of globalization raises important questions vis à vis the power and the ideology of US culture and the extent to which cultural imperialism and disorder are irrevocably interconnected. According to the Syrian philosopher Georges Tarabichi, ,globalization through the vehicle of culture encourages the disestablishment of a religious society bound to the virtues of religion causing a diminishing role of Islam to consolidate the basis of a sound cultural Islamic society and thus identity. ${ }^{21}$ For instance, the adherence to the politics of consumer economy makes Muslims prone to exterior forces that mobilize and control their consciousness paralyzing them as passive actors in this transaction. The McDonaldization of the Muslim society is one of the blinding examples behind cultural disorder. Family has lost cultural value and becomes decentred in an era when its members make the queue in a McDonald restaurant and await their turns to be served under the golden arches. Fast food habits enhance and encourage societies to take on untraditional characteristics appealing to the claim that "food is the oldest carrier of culture". ${ }^{22}$ The disruption of family values creates an impact on weaving a fragmented society that lacks solid and familial bondages. The failure to implement responsibilities to survey and to keep members within the realm of familial relation signals a crisis and a destruction of the entire social structure. ${ }^{23}$ Therefore, McDonald and many fast food industries would lead to a stripping away of identity and culture to uniform the world and to serve as agents of cultural imperialism.

On overall basis, the collective Islamic values, ways of life, principles and ideologies are pushed aside and overridden by the massive influence of the globalizing culture. In the name of a healthy cultural exchange,

\footnotetext{
${ }^{19}$ Samuel Huntington, The Clash of Civilizations and the Remaking of World Order (India: Penguin Books, 1997).

${ }^{20}$ Shahram Akbarzadeh, "General introduction”, In S. Akbarzadeh (Ed.), Islam and globalization: Critical concepts in Islamic studies, vol. 1, (London and New York: Routledge, 2006), p1-14.

${ }^{21}$ George Tarabichi, From Arab Renaissance to Apostasy: Arab Culture and its Discontent in the Age of Globalization, (London/Beirut: Saqui Books, 1999), p. 58.

${ }^{22}$ Encyclopedia Britannica http://www.britannica.com/science/cultural-globalization

${ }^{23}$ Malik Bennabi, The Quest of Culture, (Petaling Jaya and Surrey: UK and Malaysia, 2003), p. 10. 
American values are taking over the local practices and the traditional forms of dissemination of culture. ${ }^{24}$ Indeed, the global circulation of US cultural industries produces a "cross-border civilization" where "the convergence of consumer tastes and preferences" is implemented. ${ }^{25}$ For example, from Cairo to Malaysia, millions listen to pop music, wear Nike athletic shoes, and dream of Hollywood as the connoting world of glamour, excess, beauty and fashion where celebrities wear on the color of the commercials and provide a spectacle of desire and power. These icons as representative of an exploitative America turn to sell inspirations and role models to Muslims who have lost trust in established traditional forms of authority, in which "they no longer looked... to military, religious or political guidance" and who find gratification only "in immersing themselves in the lives of glamorous and flamboyant celebs". ${ }^{26}$ Such symbols of American culture have homogenized the Muslim World and strengthened an American-western culture based on the philosophy of a profitable capitalist system. To back up its neo-imperial strategy, this "open-culture" resorts to bombard the Muslim world with pornographic media. Movies, TV channels, magazines and books diffuse obscene materials to target the young generation which in turn falls prey to the temptations of mediatized spectacles that challenge the development of morality among Muslim youth. Receptive to novelties, youth absorb "shocking values" and become easily caught in this incursion with the availability and flexibility of the Internet and cyber sources. Closely associated with Antonio Gramsci's concept of hegemony, US media influence Muslims political tastes and shape their lifestyle. Programs such as "American Idol"27, the "X-Factor"28 and movies such as "Sex and The City"29, "Ellen"130 and "Sin City"31 exhibit vividly American values by broadening western domination and eclipsing the local culture. Therefore, Islamic culture and identity could be diluted and compromised due to the invisible violence of these mediated images and texts that tend to reinforce particular discourses reflecting Said's point who, in examining imperialism, reconsiders how through the consolidation of education and arts, the cultural operates to produce a shared national consciousness that nurtures a strong feeling of western supremacy and authority. He notes that:

The processes of imperialism occurred beyond the level of economic laws and political decisions, and-by predisposition, by the authority of recognizable cultural formations, but within continuing consolidation of education, literature, and the visual and musical arts- were manifested at another very significant level, that of the national culture... free of worldly affiliations (12-13). ${ }^{32}$

In addition, language is one of the make-up features of the Muslim culture being challenged by the inundating impulses of globalization. The imposition of the English language and the exportation of a western educational system threaten the deeply-rooted and holy foundations of the Arabic language. This linguistic imperialism turns to be one of the powerful arms to adopt English as the language of instruction, development and modernity. The introduction of an American-based curriculum to school and colleges connotes a radical deviation. In fact, this curriculum is alien to Islamic culture for it produces and prioritizes English as a monolanguage. Besides, the changing aims of education become discernible in this globalized age. As political, economic and cultural boundaries as well as demarcation lines are drawn, Muslim schools are imbued with US cultural norms, values and language which serve as dogmatic methods to fade away local languages. The adoption of English as an international language has transmitted US culture and ways of living to the Muslim world compounding the impoverishment and the homogenization of its culture which is bullied by the powerful enslaving forces of a commodified education. The efforts to globalize English are one of the manifestations of America's global mission to reinscribe the goals of Manifest Destiny from a cultural linguistic perspective where the dissemination of the English language may involve learners and motivate them to become members

\footnotetext{
${ }^{24}$ Wole Akande, "The Drawbacks of Cultural Globalization", Yellow Times, November 10, 2002

https://www.globalpolicy.org/component/content/article/162/27594.html

${ }^{25}$ George Tomlinson, Globalization and Culture, (Cambridge: Polity Press, 1999), p. 108.

${ }^{26}$ Ellis Cashmore, Beckham, (Cambridge: Polity Press, 2004), p. 2.

${ }^{27}$ American Idol is a singing competition series created by Simon Fuller and It began airing on Fox on June 11, 2002

${ }^{28} \mathrm{X}$ Factor is an American reality television created by Simon Cowell which was aired on Fox from 2011 to 2013

${ }^{29}$ Sex and The City is an American television romantic sitcom created by Darren Star and produced by HBO broadcasted from 1998 until 2004

${ }^{30}$ For Ellen is a 2012 American drama film written, produced and directed by So Yong Kim

${ }^{31}$ Sin and The City is an American reality television. It chronicles the day-to-day lives of five women who reside in Las Vegas, Nevada.

${ }^{32}$ Said, Culture and Imperialism, p. 12-13. 
of this imagined global community. ${ }^{33}$ The world's Lingua Franca constitutes and confirms the interlocking strategies and structures of the language of the dominant empire as a powerful symbolic system that transcends national borders and advances the goals of the global linguistic market. As part of the neo-liberal project of the US and the new unilateral orientation, English has played a predominant role in praising cultural imperialism. The TESOL and TEFL (the teaching of English to speakers of other languages) are significant exporting agents and one of the vital and dynamic dimensions of linguistic neo-imperialism that exerts its grip over the Muslim world. The asymmetrical relationship is further evidenced in the way learners are becoming the forever others "continuing the colonial storyline". ${ }^{34}$ Therefore, English is the soft weapon aimed at extending ideological control while veiling ideological hegemony with the virtues of development to further the colonization's legacy of the American culture that many Muslims still worship as "a point of modernity". ${ }^{35}$

As Said once pointed out, the United States does not want "to be an imperial power like the others it followed, preferring instead the notion of 'world responsibility' as a rationale for what it does. Earlier rationales - the Monroe Doctrine, Manifest Destiny, and so forth - lead to 'world responsibility,' which corresponds exactly to the growth of the United States' global interest after World War II". ${ }^{36}$ Hence, the rhetoric of the White Man's Burden and the reinvigoration of the ideological concepts of Manifest Destiny and Exceptionalism become firmly grounded on the transmission of US culture as an impetus and a model for the rest of the world where America relies on its cultural power to reign, to subvert the world to its ideologies and thus to repackage cultural globalization as a new interpretation of colonialism. Yet, this new imperialism is strongly involved in the multi-dimensional crisis facing the Muslim world. This liberal order inspired by cultural hegemony brings American propaganda's promises and sets its machinery in motion. The injustice and the inequality espoused by the American-controlled world order have generated the seeds for chaos which is based on elitism and polarization between the wealthy North and the impoverished South and mainly the Muslim societies.

\section{EXCLUSIONARY/RADICAL NATIONALISM VS PROGRESSIVE MOVEMENTS: THE QUEST FOR WORLD ORDER?}

Concerns that local and traditional Islamic culture and identity are dissolved into a cross-cultural consumerism have engendered a new reading of the traumatic impact of American globalization. The loss of the Arabic language, local habits, traditional teachings of Islam and the social-religious guidelines prescribed by the holy Quran, have fuelled anger and frustration among many Muslims who resort to foster a type of "nationalism" yet loaded with exclusionary ethics. In fact, the emergence of radical cultural nationalism reflects the extent to which American imperialism has been detrimental and one-sided. The religious fervour and the commitment to Islamic cultural identity and rooted tradition have spawned many violent movements in the name of Islam which have been catapulted to center stage in politics. The longing to revive a distant past by frozing cultural westernization, spur their motivations to protect and therefore to revive an endangered, threatened and disvalued Islamic culture. Indeed, this exclusionary nationalism is the mere outcome of an explosion of pent-up grievances. Exclusion and marginalization from the cultural sphere plays a powerful role in boosting and in radicalizing the orientations of such movements which make the purity of their religion and culture the central theme of their ideology. To hunt moments of glory and an imaginary past in which their culture was unsullied, anti-globalization movements in the Muslim world pervert into intolerant and even violent exclusion of all that is not orthodox by escaping into the same moral justification of using the American Manichean discourse of "us" vs. "them". Like US anti-communism campaigns or the Soviets efforts to get rid of agents of imperialism, these exclusionary movements long to challenge the homogenizing process imposed by a foreign culture and thus to extend the virtues of Islam; a pursuit that may justify and legitimize holy wars of exclusion and extermination described by Benjamin Barber as "Jihad". In other words, cultural fundamentalism operates within realms of resistance to denounce the ideological fundaments of the US culture as spoiled by selfish consumerism and economic profits and to portray anti-Americanization sentiments as being driven by religious-political principles. The ultimate objective is to propel the diffusion of anti geo-political and anticultural discourses and to pave the way to the emergence of alternative counter powers and concepts of "order".

This chauvinistic attitude and the monolithic approach mirrors what Fred Halliday describes as "reciprocal stereotyping" ${ }^{137}$ from the Muslim world and the west ending up with mutual rejection. This trend

\footnotetext{
${ }^{33}$ Stephan Ryan, "Language Learning Motivation Within The Context of Globalization: An L2 Self within an Imagined Community in Language Studies", International Journal (3).1 (2006):23.45.

${ }^{34}$ Angel Lin and Allan Luke, "Postcolonial Approaches to TESOL", Special Issue of Critical Inquiry in

Language Studies 3 (2006): 2-3.

${ }^{35}$ Ibid, p. 69.

${ }^{36}$ Said, Culture and Imperialism, p. 43.

${ }^{37}$ Fred Halliday, Islam and the Myth of Confrontation: Religion and Politics in the Middle East, (London: I. B. Tauris Publishers, 1995), p. 29.
} 
objectifies Muslims as slaves and longs to enclave them within the restrict rules of seclusion and exclusion. The imposition of an "Islamic world order" based on koranic principles and cultural values of social order become the civilizing mission of these exclusionary movements which advocate violent and extreme confrontation to reestablish the "dream of pan-Islamism" deemed as Jihadism in the path of god. ${ }^{38}$ Notwithstanding Michael Hardt's argument about resisting and repulsing empire (mainly the American empire) by sustaining "nonplaced" world opposition to denationalize US sovereignty and its pluralistic yet soft forms of governance, ${ }^{39}$ it is possible rather to refer to Homi Bhabha insight that marginalized cultures grow to shift from invisibility to visibility where the voices of "exiled groups" frame a new space of communication with convoluted social realities and cultural areas (2004).

In his discourse woven around the key idea of "Islamic world order", the Sheikh Safar al Hawali ${ }^{40}$, as one of the key figures of opposition in Saudi Arabia, identifies the USA as both a universal example and an enemy whose target is "humiliation" through soft "subjugation and destruction". ${ }^{41}$ Using Said's Orientalism, he employs concepts of geographical imagination to perpetuate the imaginaries of exclusion and inequality that end up jailing the Muslim world into backwardness and barbarity where the world of oppressed (musta' dafun) and the world of arrogant (musta' kbarun) converge to create a discourse of condescension orchestrated on the positive presentation of the United Sates and the negative homogenous representation of the Muslims and their cultures. Such stereotyping that have always permeated the relationship between the US and the Muslim World from the old days of imperialism and colonialism to today's "soft power" strategies lurking within cultural neoorientalism have acted as a catalyst for the spawning of radical Islamism and the launching of "holy wars".

Muslim Brotherhood Group in Egypt or Al Qaida in Afghanistan perpetuate the ethics of radical Islam to counteract the discourse and the ongoing forces of Americanization that seem in their views to bleach the ideals of the Islamic world and its culture with hegemonic principles based on the premises of relief, development, emancipation and empowerment. A more uprising of such radical movements finds its way to post-revolutionary Tunisia. They advocated the need to create a societal project suited to the national character of the country. The surge in Islamist and their cultural-political "militancy" was strengthened by a cluster of radical salafi currents who favored terrorism as a catalyst for popular uprisings to dismantle the civic "westernized" state and build on its wrecks the Islamic state. These included mainly Al Jabhat al Islamiya Al Tunisiya (Tunisian Islamic front, FIT), Ansar-al-Shariaa and Hizb al Tahrir al-Islami (Islamic Liberation Party, PLI). These movements sought not only to end the authority of political regimes but also to seize the opportunity to challenge the secularized-westernized social and cultural order that predominate in Tunisia and to replace it with an ultra-conservative model inspired from wahabism. Opposing what they consider as "converting waves", they advocated a return to what they saw as the purity of the first generation of Islam, the salaf. Their ideas were deeply influenced by the teachings of Ibn Taymiyah ${ }^{42}$ (1263-1328), who saw the state as an adjunct of religion and opposed discursive theology. For instance, the flourishing of such radical movements as a counter force to the neo-Orientalist ideology reduces Muslim societies into one of the relatively sterile incarnations of the cultural, historical and ideological diversities within Muslim civil societies. The resort to power, violence and the imposition of "conversion" to their 'tainted' version of Islam spawn in turn detrimental chaos and disorder. It foregrounds that the new recipe for "restricted modernity" and the march towards independence from non-Islamic cultural and political infiltrations have been rather founded on the attempt to "kill" the cultural and historical foundations upon which rest the Muslim' societies. What these movements have engendered seems nothing but a violation of the inspirations and aspirations of Muslims. By portraying themselves as the invaders or fatihs, whose holy and sacred mission is to spread the 'true culture of Islam' amongst the heathen population and to stop what they consider as the "reformed and refined version of Islam", their Islamist orbit spared no effort to fragment the society into 'real Muslims' and 'infidels' (those who are against their Islamist project) immediately after the fall of the secular regime. More hardliners of these so-called Salafist groups who tend to impose their own vision of society, culture and religion as opposed to globalization and its Americanized ethics are reflected on their longing to impose the burquaa ${ }^{43}$, the niquab ${ }^{44}$ or the quamis ${ }^{45}$

\footnotetext{
${ }^{38}$ Abubaker A Bagader, "Contemporary Islamic movement in the Arab world", in Ahmad, A. S., \& Donnan, H. Islam Globalization, and post modernity, ( London: Routledge: 1994), p. 117.

${ }^{39}$ Antonio Negri and Michael Hardt, Empire, (USA: Rvard University Press, 2000).

${ }^{40} \mathrm{He}$ is a well-known Saudi Islamic scholar. He came to prominence as a leader of the Sahwah movement which opposed the presence of US troops on the Arabian Peninsula.

${ }^{41}$ Mamoun Fandy, Saudi Arabia and the Politics of Dissent, (New York: St. Martin's Press, (1999), p. 71.

${ }^{42}$ A controversial, medieval, Sunni Muslim theologian, whose radical views and anti-classical interpretations of Islam are believed to have considerable impact on contemporary Wahabism Jihadism and Salafism.

${ }^{43}$ The burka is the most concealing of all Islamic veils. It covers the entire face and body, leaving just a mesh screen to see through.
} 
at the expense of what they deemed as the westernized clothing style (hip hop jeans, short skirts, biquini... ) as well as the proliferation of many koranic kindergarten where little veiled girls $\left(\right.$ with hijab ${ }^{46}$ ) were mobilized at a very young age to be taught the rules of Islamic culture with a wahabian character. Their call to ban music, cultural-artistic manifestations, to stop teaching English in schools and universities and even attacking the very form of American sovereignty (US embassy in Tunis) highlight that the radicalization of Islam ends up intensifying social turmoil and disorder that present a danger for the stability and cohesion of the country.

However, other progressive and moderate movements view globalization as a power game and Muslims have recourse to two choices either to resist by means of taking distance, denying and thus consolidating an impermeable culture adjusted to meet the new challenges and the onslaught of globalization or to be marginalized and integrated passively into this inevitable process. This trend emphasizes that the global flows of social, economic, cultural and technological changes can be grasped by Islam as an encompassing religion. Thanks to its reservoir of values, ideas and inspirations, it can derive a contemporary code to shift the equation from contradictions to only "integrating differences" and thus to get immersed into the process of globalization and to win many advantages due to which Muslims can cleverly adapt their culture and identity to equal levels with the new ethics of globalization. From this perspective, globalization should be seen as an "awakening shock" to evaluate the immunity of their values in regard to the higher requirements of the modern age. Far away from being passive receptors of the tides of globalization, Muslims are quite aware how to balance between the increasing global waves and their very cultural values and identity. Local culture remains a powerful catalyst in their daily life which continues to shape their particular norms.

The fact that residents in Indonesia, Morocco, Egypt and Lebanon eat at McDonald restaurants, watch a Hollywood blockbuster or wear Levis jeans and Nike shoes do not "convert" them into "Americans". This eagerness and desire to share the fruits of globalization does not obscure their willingness to celebrate the distinctiveness of their culture which seems much more resilient than many others think. To incorporate and to embrace foreign culture can to an extent change national culture but not destroying it. This cross-border cultural exchange can increase diversity and remove individuals from the tyranny of the place and the old-days methodology. Many successful examples come from moderate and modern Islamic movements such as the Turkish Gülen Movement ${ }^{47}$ which symbolizes the pragmatic approach to globalization while maintaining that anti-westernism and anti-Americanism ${ }^{48}$ would force the Muslim world out of civilization. With a tolerant and liberal ideology, modernization and Islam do not stand as foes but rather complement each other with fervour for compromising globalization, post-modernity and the race for international competition.

\section{CONCLUSION}

American globalization and the circulation of liberal hegemonic principles fuel the dynamics and ambitions of cultural imperialism to exert its firm grip on the rest of the world. This ideology embodies a revival of the old western mission to control and to subjugate far-flung territories. In fact, US culture becomes an impetus in the long journey of neo-colonialism where cultural artifacts are emblematic of invisible violence. As such, it serves as a camouflage to mask the hidden intentions of the dominant power in securing its economic and political interests while discarding cultural diversity and eclipsing local and regional eccentricities. ${ }^{49}$ Thus, developing meaningful cultural policies is essential for the U.S. to authenticate its commitment to global cultural diversity and challenge the world's suspicions of the existence of an American imperial agenda. The current resurgence of anti-Americanism is reflected in many Islamic trends which tend to explain and to address the impacts of cultural globalization. While exclusionary nationalism movements seek to reestablish a "world order" based on the holy teachings of Islam within exclusionary codes, moderate and progressive ones long to portray globalization, Islamic culture and identity as complementary. Lately, voices becomes louder to move far beyond

\footnotetext{
${ }^{44}$ The niqab is a veil for the face that leaves the area around the eyes clear. However, it may be worn with a separate eye veil. It is worn with an accompanying headscarf.

${ }^{45}$ The term qamis also known as kameez and qameez refers to a long tunic or gown worn in Islamic culture.

${ }^{46}$ The word hijab comes from the Arabic for veil and is used to describe the headscarves worn by Muslim women. These scarves come in myriad styles and colours. The type most commonly worn in the West is a square scarf that covers the head and neck but leaves the face clear.

${ }^{47}$ Established by the Turkish preacher Fethullah Gulen who has lived in the US since 1999, the Gulen is an Islamic transnational social movement praised for its pacifist, liberal and modern oriented version for Islam contrasting and rejecting the extremists' schools of Salafism.

${ }^{48}$ Anti-Western Islamic movements generally refer to Sayyid Qutb (d. 1966) "who offers a critique of modernity as jahiliyya, a kind of global pathology." Roxanne L. Euben, "Mapping Modernities, 'Islamic' and 'Western"' in Fred R. Dallmayr, ed., Border Crossings: Toward a Comparative Political Theory (Lanham, MD: Lexington Books, 1999), 19.
} 
imperialism and cultural clahses to reach the peaceful shores of what many philosophers such as Charles Taylor, Robert Nisbet and Armita Etziona call "communitarianism" which presents itself as the guiding path to a new global order to serve the genuine interest of humanity and to attain a cohesive relationship between individuals and communities.

\section{Works Cited}

[1]. Bagader, Abubaker A. "Contemporary Islamic movement in the Arab world". In Ahmad, A. S., \& Donnan, H. Islam Globalization, and post modernity. London: Routledge: 1994.

[2]. Bennabi, Malik. The Quest of Culture. Petaling Jaya and Surrey: UK and Malaysia, 2003.

[3]. Cashmore, Ellis. Beckham. Cambridge: Polity Press, 2004.

[4]. Euben,Roxanne L., "Mapping Modernities, 'Islamic' and 'Western"” in Fred R. Dallmayr, ed., Border Crossings: Toward a Comparative Political Theory (Lanham, MD: Lexington Books, 1999), 19.

[5]. Friedman, Thomas. "Commentary Why Those Angry Men Want To Kill America.” The New York Times. August, 25 1998:7.

[6]. Fukuyama, Francis. The End of History and The Last Man. New York Press, 1992.

[7]. Gabler, Neal. Life The Movie: How Entertainment Conquered Reality. Toronto: Random House of Canada, 1998.

[8]. $\quad$--------. Walter Winchell: Gossip, Power and The Culture of Celebrity. London: Picador, 1995.

[9]. Gilpin, Robert. "The Politics of Transnational Economic Relations." In Keohane, R.O. and Nye, J. Power and Independence: Politics In Transitions. Boston: Addison Wesley, 1971.

[10]. Gilroy, Paul. There Ain't No Black in The Union Jack: The Cultural Politics of Race and Nation. University of Chicago Press: Chicago, 1995.

[11]. Gramsci, Antonio. "Hegemony, Relations of Force, Historical Bloc". In Antonio Gramsci Reader. Eds. [1]. David Forgace and Eric J. Hobsbawm. New York: New York University Press, 2000.

[12]. Halliday, Fred. Islam and the Myth of Confrontation: Religion and Politics in the Middle East. London: I. B. Tauris Publishers, 1995 .

[13]. Hardt, Michael and Antonio Negri. Empire. USA: Rvard University Press, 2000.

[14]. Huntington, Samuel. The Clash of Civilizations and The Remaking of The World Order ((India: Penguin Books, 1997).

[15]. Hurrel, Andrew and Ngaire Woods. "Globalization and Inequality." In Millennium. Journal of International Relations 24.3 (1995):447:470.

[16]. Lin, Angel and Allan Luke. "Postcolonial Approaches to TESOL." Special Issue of Critical Inquiry in Language Studies 3 (2006): 2-3.

[17]. Marcuse, Herbert. One Dimensional Man: Studies in The Ideology of Advanced Industrial Society. Boston: Beacon, 1964.

[18]. Renehan, Edward. The Monroe Doctrine: The Cornerstone of American Foreign Policy. New York: Info Base Publishing, 2007.

[19]. Rosati, Jerel A. The Politics of United States Foreign Policy. Orlando: Harcourt Brace College Publishers, 1999.

[20]. Ryan, Stephan. "Language Learning Motivation Within The Context of Globalization: An L2 Self within an Imagined Community in Language Studies.” International Journal 3.1 (2006):23.45.

[21]. Said, Edward W. Culture and Imperialism. New York: Knopf, 1993.

[22]. Shahram, Akbarzadeh. "General Introduction". In S. Akbarzadeh (ed.) Islam and globalization: Critical Concepts in Islamic Studies. London: Routledge: 2006.

[23]. Strange, Susan. "Towards a Theory of Transnational Empire". In Czempiel and Rosenau (Ed) Global Changes and Theoretical Challenges. Lexington: Lexington Books, 1989.

[24]. Tarabichi, George. From Arab Renaissance to Apostasy: Arab Culture and its Discontent in the Age of Globalization. London/Beirut: Saqui Books, 1999.

[25]. Tomlinson, George. Globalization and Culture. Cambridge: Polity Press, 1999. Electronic Sources

[26]. Akande, wole. "The Drawbacks of Cultural Globalization". Yellow Times. November 10, 2002 https://www.globalpolicy.org/component/content/article/162/27594.html

[27]. Encyclopedia Britannica http://www.britannica.com/science/cultural-globalization. 